\title{
Engaged Academics as Activist Professionals: Privilege and Humility in Addressing Knowledge Divides
}

\author{
Pamela Oliver \\ University of Wisconsin - Madison \\ Pamela.oliver@wisc.edu \\ orcid.org/0000-0001-7643-1008
}

'This is an author-created, un-copyedited version of an article accepted for publication in Research in Social Movements, Conflicts and Change, Volume 43, Bringing Down Divides, Lisa Leitz and Eitan Alimi, eds. Fall 2019 (http://www.emeraldgrouppublishing.com/products/books/series.htm?id=0163-786X)

keywords: engaged research, action research, public sociology, activist professionals, criminal justice, racial disparities

\begin{abstract}
The cross-pressures and tensions for engaged academics are like those of other activist professionals and advantaged allies. Academic knowledge is most useful when it is put into dialog with the knowledge and experiences of others and academics use their skills to bring new information into community discussions, to provoke discussions, and to carry knowledge between groups. Academics should listen as well as talk, recognize and respect the differences among community members, and actively attend to and seek to amplify the voices of those who are most oppressed and marginalized.
\end{abstract}

This paper began as informal remarks on several topics I made at a panel on engaged social movements scholarship in 2011 (Oliver 2011), where Greg Maney was a fellow panelist. When I was asked to contribute something to a volume honoring Greg because I had been his PhD advisor, I thought of this paper. The original presentation and this paper draw primarily on my own experiences across 18 years in working to address issues of racial disparities in criminal justice in Wisconsin. My engagement began from the bottom up as a volunteer, not from the top down as a professional project grounded in one of the academic traditions of engaged scholarship. In my after-the-fact reading of some of the huge academic literature on this topic, I have been impressed both by the high level of self-reflexivity in much of this writing and by the wide diversity of orientations and practices described. At the same time, much of this literature seems to treat academics as a species apart from other people. I argue that engaged academics are best understood as a type of activist professional, by which I mean people who pursue social change goals using their professional skills or institutional position. Although my own standpoint is that of an advantaged ally, I also point to activist professionals who are rooted in oppressed communities. Decentering ourselves and seeing our actions, choices and social locations as like those of others in the field is an important step in working across divides. It may make us less pompous and selfimportant and better at paying attention to what other people are saying and doing.

\section{Overview of My Engagement}

As I have described elsewhere (Oliver 2009), I was inspired by a conference put on by local activists in 1999 to participate as a volunteer in the local reform movement to reduce racial disparities in criminal justice. I joined a forum series planning committee and offered to use my generalized research skills to prepare handouts on patterns of incarceration. This led (via a state legislator's open records request) to 
being given access to Wisconsin Department of Corrections data that no one else had, which I used (with the help of grad student Jim Yocom) to prepare PowerPoint presentations on racial trends in Wisconsin incarceration by race and offense and admission category. The data were shocking. Wisconsin's Black imprisonment rate was 20 times that of the White rate and the disparity was even higher (60) for drug offenses, making Wisconsin one of the worst states in the nation for Black imprisonment. Dane County (home of Madison) was even more disparate than Milwaukee and the trends showed a clear "smoking gun," a huge rise in Black but not White prison sentences for drug offenses after Madison police got a multi-million-dollar drug enforcement grant in 1992. People who saw the graphs were horrified and fascinated. I got invited to give talks to many audiences. Most were predominantly White, but some were predominantly Black. I was often invited to speak to groups of criminal justice professionals and was asked to give lengthy presentations to special commissions. I joined an advocacy group and stayed involved in it until it finally folded in 2011. I was asked to serve on several official task forces, boards, and commissions. Over a 15-year period, I gave over 100 public presentations and attended literally hundreds of meetings. I was also often asked by community members to perform special statistical analyses or reports for their groups, which I did on a volunteer basis.

This was not research project about the groups or about working with groups, but as I participated I listened to people, tried to understand what different people were saying, and tried to move information and perspectives around between the groups I talked with. I showed graphs of trends and talked about the policies that produced them. Audiences asked questions and offered their own interpretations. Most White audiences were shocked and distressed at the magnitude of the racial disparities. Several people have said that my presentation motivated a shift in their own activist or professional trajectory. Most Black people said the graphs affirmed what they knew and wanted to know what I was doing about it. Criminal justice professionals often talked about how the things they knew about fed into the statistics. I tried to carry information between groups. I talked to Black people about how White people shut down when they hear the word "racist," and to White people about what Black people mean when they call something racist. I listened to police explain that policing can never be random and must be concentrated where there are problems and carried that into subsequent talks, explaining that where policing happens is a key factor. I explained that nobody seriously disputes that Whites use illegal drugs as much as or more than Blacks and the debates are about who the drug dealers are and how drug markets work. I told White audiences that Black people frequently bring up the claim that the CIA was selling cocaine in Los Angeles and generally stress that Black people lack the resources to be the heads of major international drug cartels. I told audiences that different criminal justice professionals disagreed about whether revocations hearings were often waived and whether people were often revoked for trivial offenses.

It is difficult to assess my influence. In the 2000s, I was often described as the person who had drawn attention to the racial disparities issue in Wisconsin. I was a recognized and consistent presence in the local circles working on these issues. I was also known for a willingness to talk directly about race and racial discrimination. I helped write several policy reports. I gave many news media interviews. I played a specialized academic role, bringing data and a sociological interpretive lens to discussions, as I sought to emphasize structural racism rather than individual bias. Quite a few people told me they appreciated my contribution to the effort. But I was never the initiator or central force in any action, I never led or organized any group, and when I look back, I'm not sure what was accomplished.

Before 2011, the groups I worked in were dominated by Black and White professionals from the criminal justice and social service sectors and with a sprinkling of academics and community organizers. The core beneficiary constituents of the effort to address mass incarceration are stigmatized and 
disempowered Black people who are in trouble with the criminal justice system. Many are in prison. When not in prison, the conditions of community supervision often prohibit them from gathering for disruptive or even peaceful protests. Several times, an ex-prisoner on parole who was scheduled to speak at a public event was detained in jail on a parole hold and prevented from speaking with no reason given for their detention. A few of the social services professionals were themselves returned prisoners. People from lower income impacted communities were a minority presence in most of the groups. Non-professional activists often disappeared from the groups to deal with their own or family members' crises including ill health, eviction, job loss, or arrest.

After 2010 and the publication of Michelle Alexander's New Jim Crow, mixed-race groups with more volunteers and fewer professionals formed, and after 2013 there were more militant mixed-race and Black groups and protests about criminal justice issues. These more militant groups have higher visibility of lower income people and returned prisoners. My involvement with these more militant groups has been more peripheral, i.e. occasionally showing up to give an academic voice at a forum they sponsor or as a generalized affluent White supporter with no special role.

I write about my experiences as I recall them. I was not doing research about the groups I was volunteering with and I did not write field notes. Exchanges I describe that might identify individuals occurred in meetings that were legally open to the public. Exchanges that rely on private conversations have been de-identified. These unsystematically recalled stories are meant to provoke discussion and reflection about the role of academics and other activist professionals in addressing knowledge divides. I do not assert that these stories adequately represent everything that happened in fifteen years in my community, nor that what I observed would generalize to other settings, nor that I accurately represent the perspectives of others I worked with.

\section{Engaged Academics as Activist Professionals}

People with activist impulses may enter professions where they feel they may be able to do some social good while earning a paycheck. Joyce Bell (2014) discusses how Black Power activists in the 1970s intentionally went into the professions, including social work, to gain power to make changes from inside the system. Even without a Black Power ideology, many Black people entered criminal justice or social service professions with the explicit idea of using the position to benefit their community. Additionally, as movements win partial victories, they capture pieces of the state apparatus. Australian feminists coined the term "femocrat" to refer to feminists who went into government to promote female equality (Chappell 2002; Sawer 2007) and many Black and Latinx people are employed in a "civil rights bureaucracy" of offices of diversity, civil rights, or equal opportunity. There are also a wide variety of positions in government and private business in human relations or community outreach that embody or respond to social movements, as well as a wide variety of nonprofit organizations that pursue advocacy or reform. Social movement scholars have long recognized the importance of paid professional activists who work for social movements. I add to this the concept of activist professionals who intentionally use their professional skills or position to promote goals which they see as being in the service of a social movement or social reform. Whether activist professionals really promote the change they intend is beyond the scope of this essay, except to note that the same question adheres to activist academics or, for that matter, activism generally.

Activist professionals may do activism as an integral part of their paid job, as volunteers working outside the scope of their paid job, or in an in-between status. Some activist professionals do activism "on the clock" as an integral part of their job. Some professional jobs include attending meetings and promoting reform, just as the job of a professional activist includes being a community organizer or staff to a social movement organization. Many of the participants at the boards, commissions, and task forces 
were there as a part of their job, including some of those most committed to the effort. Being paid to promote reform does not necessarily make the activist any less committed. To the contrary, committed activists often seek positions where they will be able to promote reform.

The academic parallel to doing activism on the clock are academics whose research agendas coincide with working for social reform. One large branch of such work which I do not address are those whose research is about an oppressed group, where the researcher believes they are serving the group by writing about them or magnifying their voices. I focus on research that is for a group, typically focused on actions of elites or strategies for change. Feagin, Vera and Ducey (2015) provide a comprehensive overview of what they call "liberation sociology," which has an explicit stance or moral standpoint in favor of increasing social equality and challenging hierarchies, and especially addressing the aims and interests and perspectives of oppressed people. There is a well-developed and differentiated action research tradition that is supported in some universities by course work and textbooks, although not necessarily housed in sociology departments. The hallmarks of the action research tradition are democratic collaboration with groups or organizations or communities, a focus on solving practical problems and generating social change, and a reflexive orientation that attends to the relation of the researcher to the community and to power relations in the community (Bradbury-Huang 2010; Brydon-Miller, Greenwood and Maguire 2003; Greenwood and Levin 2006). There are different schools of thought within this tradition that vary in the relation between the researcher and the community group, the extent to which oppressed communities are the focus of attention and researchers seek to develop the ideological consciousness of groups, and the nature of prescribed discussions and collaborations. Although all action researchers invoke ideals of community participation, a radical strand in this tradition that calls itself participatory action research or just participatory research draws on Gramsci's discussion of organic intellectuals and Freire's ideas of critical pedagogy and seeks to foster ideological development and understanding of larger political economic forces among the oppressed while working in a participatory manner to help oppressed people identify and solve their own problems (Brook and Darlington 2013; Schiller 2011; Stoecker and Bonacich 1992). Stoecker (1999) identifies three academic roles in participatory action research: the initiator who gets things going but never passes it off to the community, the consultant who does what they're asked but doesn't train others, and the collaborator who works with and trains others.

Within the study of social movements, there is a well-established tradition of using social movement theory in a participatory framework to help guide movement planning, including Abraham and Maney (2012); Brady and Lesniewski (2018); Carragee (2005); Healey and Hinson (2005); Johnston (2007); Ross (2005); Ryan (2005); Ryan, Jeffreys and Blozie (2012). Many others have written about doing collaborative research with community groups to plan their strategies or actions, including Hoynes (2005), Morton et al. (2012), Sekhon (2006) and Khadse et al. (2018).

My racial disparities work could be understood as a type of action research because it fed into the work of community groups, but unlike self-conscious action researchers, I did not view this work as my research agenda, was not working from a coherent paradigm, was not systematically monitoring the effects of my interventions, and was not convening groups to reflect on what research or actions to do. I do understand the criminal justice system as integrated with the system of political and economic control and repression (Oliver 2008), spoke of the mass incarceration of Black people as morally wrong for its destructive consequences for Black communities, and tied criminal justice issues into the larger political economic context. I joined groups when Black professional reformers asked me and worked collaboratively with them. I did little to educate or empower oppressed people, although I did pay attention to what marginalized and disadvantaged people said and sought to promote their voices in policy reports. 
One issue for academics working "on the clock" is which direction resources flow. Sometimes community groups seek people to do research work for pay, typically offering small amounts suitable only for part-time side jobs. Sometimes academics, like social service professionals or community organizers, seek money from community groups, governments or charitable foundations to pay their salaries to do things they believe will benefit the community. Action researchers may be paid by community organizations. In the 1970s, when I was participating as a volunteer in neighborhood organizations in a different city, representatives of the School of Social Work spoke to the interneighborhood council, characterized social work as "the radical profession," and asked the council to help fund their project. Even when not asked for money, community members may be asked for their time in a project where the researchers are paid. Such situations may lead community members to feel exploited.

At the other extreme from being "on the clock" as an activist professional, people in any occupation, including academics, may participate entirely "off the clock" as a volunteer in social change groups, with no expectation of any positive impact on their career. As a famous example, Professor Jo Ann Robinson at Alabama State College was one of the key organizers of the Montgomery Bus Boycott. With the aid of students, she made 35,000 leaflets advertising the boycott using a college mimeograph machine (Berkhalter 2006). Although you don't need an advanced degree to run a photocopier or make telephone calls or arrange transportation, having the degree does not prevent you from doing the work if you have access to the needed equipment and are willing to do it.

In addition to doing what anyone else can do, activist professionals may use their professional skills in the service of the movement with no expectation of career benefit. Lawyers may provide pro bono legal services to movement organizations. Carpenters may volunteer their time building sheds or offices or booths for the group. Academics may similarly use their skills to do pro bono research and report writing as activities entirely apart from their academic careers. The marker of the extreme end of the volunteer spectrum is not putting these activities on their c.v. There are doubtless many academics whose contributions to social movements remain unremarked because they don't publicize them.

Between the extremes of on the clock and pure volunteering, activism may be a voluntary extension of the professional's job, involving extra meetings or effort beyond what is normally required, or is a way of performing the job that pulls in reform concerns. Activist professionals may seek to promote reform from within. Supervisors may choose to monitor their systems for bias, prepare reports, or do intra-agency advocacy. Lawyers and doctors may be expected to do pro bono work as part of their professional obligations. Police officers, teachers, and business people may also be expected to be visible off the clock in community service activities. Academics similarly have "service" obligations. Not all service is activism, but in some cases, professionals both pursue reform or social change and do it in a manner that overtly represents themselves as having a set of qualifications that are linked to their profession and claim it as part of their larger professional role. I would consider listing academic activism on the c.v. as service, as I do, to fall in this middle range.

Academics may also sometimes seek to gain some professional benefit out of movement work they initiated as a volunteer, as when academics who have volunteered in a movement write retrospective case studies or theoretical reflections on the group or their work with it for academic publications like this one or the many published case studies of social movement groups. It is also common for academics who do research for a movement to obtain access to the data and write spin-off publications for academic journals, as I did with a survey I conducted of participants at a neighborhood convention in the 1970s (Oliver 1983) and Hoynes (2005) reports doing with the data he collected and analyzed for a movement group. 


\section{Advantaged Allies and Professional Intersections}

Activist professionals are often what McCarthy and Zald (1977) call conscience constituents and Droogendyk et al. (2016) call advantaged group allies: relatively privileged people who support a movement but are not beneficiaries of it. Both Droogendyk et al. (2016) and McCarthy and Zald (1977) discuss the tensions that arise between oppressed people and their advantaged group allies because they have different experiences and interests. Based on a review of multiple case studies, Gary Marx and Michael Useem (1971) argue that advantaged group allies tend to want to control organizations and are more likely to be able to do so because they have more resources and political power. Peters (2005) quotes an activist saying academics would do better to shut up in public and stop trying to control activist projects and instead be disciplined about using class privilege and expertise to benefit others, share resources, take guidance from movements, and be willing to help with the less fun parts of the work.

Advantaged allies tend to dilute the oppositional identities that promote empowerment among the oppressed (Droogendyk et al. 2016). Advantaged allies often portray people as victims and use disempowering rhetoric or seek to dissuade people from radical action (Emejulu 2015; Maney and Abraham 2008). Oppressed people are generally more radical in their goals and tactics than allies and are less concerned with their relations to other movements (Marx and Useem 1971). Many writers note the unconscious White supremacist assumptions and practices among Whites who seek to be antiracist allies of Black movements (e.g., Appel 2003; Brown 2017; Hughey 2007).

I was an advantaged ally. Most of my public speaking was to predominantly White audiences to gain their attention and support. Some Black community members said Black people should see my graphs to know what they are up against, but mostly Black people felt they already knew what the problem was and wanted to do something about it. Some Black people said they appreciated my being a White person willing to talk about the issue, but others were justifiably upset that I got attention while Black people had been ignored when they said the same things.

The position of engaged academics and other activist professionals involves two dimensions: (1) the person's own professional expertise and standing, which nearly always gives them some structural advantage and (2) the person's personal or demographic relationship with the oppressed group. Some activist professionals come from oppressed or marginalized groups. Some are serving the same oppressed communities where they grew up. Others grew up in a demographically similar community in another place. They are advantaged relative to other oppressed people and may have been reared with relative privilege compared to others in their community, but they are still not in the same position as outsiders from advantaged majority backgrounds. Most of the Black activist criminal justice professionals I encountered had grown up in economically disadvantaged segregated areas of big cities in the Midwest; many had relatives who had been arrested or incarcerated, and all had personally experienced racial discrimination. They often saw themselves as accountable to their communities, or as using their professional position to help people or empower communities or give voice to the experiences of their communities. Of course, their present class position and occupation influenced their views, but they were still not in the same position as White professionals from affluent backgrounds.

There are academic parallels for activist professionals from oppressed or marginalized backgrounds. Sociological traditions grounded in the work of DuBois and Black Feminists and postcolonial scholars emphasize research and action rooted in the experiences and agency of oppressed people in the face of structural constraints on their actions (e.g., Brewer 2005; Brown 2017; Feagin and Vera 2001; Feagin, Vera and Ducey 2015; Goodson 2005; Hill Collins 1986; Hill Collins 2009; Hill Collins 2016; Morris and Ghaziani 2005). A growing body of research in social movements is by scholars who identify with these 
traditions in studying the movements of marginalized groups, including women of color working for reproductive rights (Luna 2016; Luna 2017; Luna 2018; Luna 2010; Luna 2011), movements by Latinx people of different immigration statuses (Burciaga 2016; Burciaga and Martinez 2017; Martinez 2005; Martinez 2008; Martinez 2014) or Arab immigrants (Azab and Santoro 2017).

Regardless of their own origins, activist professionals also differ in the duration and depth of their engagement with and commitment to a community or movement. Some have been engaged for decades and are known and either trusted or distrusted based on long experience, while others are new and untested. Some are students or itinerant researchers whose involvement is inherently transitory and their personal stakes entirely immediate, while others expect to be in a community for the foreseeable future and have longer-term stakes. Academics are more likely than other activist professionals to be transitory. Reiter (2015) writes movingly of the material reality of the uprooted scholar who has left their home community, is always on the move due to academic precarity or ambition, seeking to make meaning in poor communities of choice to whom they have little accountability, globalized scholars at home everywhere and nowhere. The writers in the volume edited by Reiter and Oslender (2015) reflect on their different relations with the communities where they have mingled activism and research. Even when they shared a racial and social background, most reflected on the lower risks they faced as outsiders who could leave.

\section{Cross Pressures of Activist Professionals}

The academic literature is full of discussions about the cross-pressures of activist academics. Many have written about the ways the structures of the academy make it difficult to combine career advancement with deep community engagement or empowering oppressed people. Feagin, Vera and Ducey (2015) provide a comprehensive overview of these debates and of the many ways sociologists have sought to do work to center the interests and perspective of oppressed people. Burawoy (2005) discusses the history of the professionalization of sociology, graduate students being socialized out of doing engaged or committed research, and disciplinary battles between sociology and other social sciences; (Brewer 2005) critiques this telling for its blindness to the work of women and people of color. Croteau (2005) discusses the way sociology split off from social work and how this has played out in ongoing gaps between academic norms and community needs.

The identified pressures against engaged scholarship include the professionalized standards of the academy, the intentional rarefication of academic discourse, the corporatization of universities and the rise of publication metrics (Burawoy 2005; Croteau 2005; Gamson 2005). These issues echo through all the essays in the American Quarterly forum on Academia and Activism (2012, Volume 64 No. 4). Several academics have written about the straightforward problem of time commitments and balancing engaged activism with publishing research articles (Cancian 1993; Croteau 2005; Reiter 2015). Most agree that the customs and rhythms of academic research are different from those in the activist world (e.g., Croteau 2005; Dawson and Sinwell 2012; Hoynes 2005). Most who do engaged scholarship emphasize that the kind of research and writing that is useful to community groups is produced on a different time table and in a different format than research for academic audiences.

Like activist academics, activist criminal justice professionals also experienced cross-pressures. The Black activist professionals were in for the long haul; they could not give up on the issue and move on to something else. They were genuinely committed to reducing racial disparities and often used their institutional positions to address them. Police officials disciplined officers for disparate traffic stops revealed in internal data analyses. Judges paid attention to racial patterns in charging and sentence recommendations and tried to push back at things that seemed unfair. Juvenile justice officials wrote guidelines to constrain social workers' use of confinement. At the same time, they wanted to keep and 
even advance in their jobs and had perspectives affected by their occupations. They had to work their reform efforts in around the other demands of their specific job. They had to maintain cordial relationships with other professionals who did not share their reform goals. They were all bound by the norms of their professions.

Each person's professional standpoint constrained their views. An example played out at one meeting. First a Black judge criticized a Black police official for not being a strong enough advocate of reducing racial profiling in policing; the back and forth involved the police official citing limits on the ability to constrain officers in the field. Fifteen minutes later, the tables were turned when the police official said that judges should take responsibility for detecting and eliminating bias in the prosecution of cases in their courts and the judge objected, citing the inappropriateness of judges sanctioning prosecutors. White school system representatives often voiced concerns that some teachers were biased toward Black children but nevertheless reacted with indignation when someone criticized the school system in general. Everybody from every institution alluded to specific people within their institution who were biased or resistant to reform efforts, but nobody seemed to feel able to tackle this issue directly in their own institution.

\section{Conflicts of Interest}

Many discussions of engaged or participatory research take the group or community that the knowledge is for as a given, either because there is a well-defined group they have a relationship with or because there is an implicit binary that the research is either "for" oppressed people or is not. If it is not "for" the oppressed, then it is either "for" one's own academic career or abstract social science, or "for" maintenance of the existing hierarchies. Although the seven writers in Social Problems forum (Burawoy et al. 2004) on public sociology all mention issues of "knowledge for whom," they pay essentially no attention to issues of the power relations between researchers and communities or to the issues of oppressed people as publics. But there can be conflicts within a community about their interests and legitimate disagreements about which policies would benefit them. David (2002) describes work in two participatory action research projects where he recognized that there were crucial questions about who was the "local community" to collaborate with: in one case, there were too many groups to consult all and in another there were competing groups; in both cases it was necessary to decide whom to include. Gedicks (2004) describes how he was initially asked by Ojibwa leaders to provide technical help opposing an Exxon mine on their reservation by researching what Exxon had done in other locations. However, divisions developed among the Ojibwa about whether to oppose or support the mine and Gedicks was asked to separate himself from the Ojibwa and shifted into organizing an allied White group opposing the mine. Oslender (2015) writes about problems in failing to make community connections in fieldwork, often because of conflicts within the community. In her study of community groups seeking to reduce crime and drug use in a poor Black community, Jones (2018) describes three different types of local groups seeking to improve the community, one made up of members of what she calls the "credentialed class," another made up of what she calls "street brokers," and a third she calls "activists." Every activist, professional or otherwise, wittingly or unwittingly, takes a position within these complex fields of competing interests and ideologies.

There was latent racial tension about the allocation of jobs in the human services sector in the groups I worked with. Much social service work is contracted out to nonprofit organizations and most contracts went to a few large White-dominated agencies, even though those needing services were mostly Black or Hispanic. Black social workers complained about discriminatory employment practices by White agencies and thought more contracts should go to minority-run agencies. This issue underlay the first racial split in one advocacy group I participated in, as Black activists prioritized this issue and 
Whites did not. When it came up again several years later in the county's task force on racial disparities, the issue was described as providing "culturally appropriate" services. Black and other minority people assumed that you must be from a culture to enact it and that having their own bodily selves providing services is what made them culturally appropriate. White service providers felt they could address cultural appropriateness by training White people in cultural differences. Because of its sensitivity in involving the direct material interest of who would have jobs and who would not, this issue was rarely discussed in clear job allocation terms as a racial conflict of interest, but it was an ongoing source of latent conflict. Of course, there were also conflicts and competition within minority groups about the allocation of scarce resources, ideology, and whose leadership would be recognized.

The latent tensions I saw among social service professionals mirrors tensions in the academy. Scholars from marginalized backgrounds say that they in their embodied selves bring needed perspectives of the marginalized into the academy, while those of us from majority backgrounds often think that we can address the issues by listening to and reading the work of marginalized people without paying them or making our own jobs less secure. And, of course, there is competition as well as cooperation among marginalized scholars themselves for the academic crumbs available to them.

Everybody in a social movement has individual interests regardless of their occupation or class position, regardless of whether they are advantaged or disadvantaged, insiders or outsiders. Academics sometimes write as if academics are interest-free neutral observers recording others' mixed motives and interest conflicts, and other times write as if there is a homogenous collectively-oriented "community" with which the academic engages. Sometimes engaged academics critique activist professionals for having a relatively elite class position as if they, the academics, are classless. A better model sees engaged academics as parts of their communities and qualitatively like the other actors in the setting in bringing a standpoint and a mixture of individual and collective motives to the interaction. Just as academics often seek academic prestige for their engaged scholarship, community organizers or leaders or other activist professionals seek prestige, honor, or power in their work in a movement or reform project. Some view the current project as a stepping stone toward a professional or political goal. Volunteers and disadvantaged people also have individual interests such as wanting to become respected as leaders or to generate a stable income.

\section{Listening and Sharing Across Divides}

Statistical data like I could produce did not substitute for grounded knowledge about systems but had the potential to shed light on how systems were working and hold them accountable. My graphs and presentations were considered by many reformers to be very helpful in both calling attention to problems and pinpointing where in the system the problems were largest. Similarly, people often found it helpful to reflect on the broader social forces that were impacting the systems they were trying to change. My contributions were valuable because I thought consciously about how to convey information in an accessible manner and brought that information in dialog with what other people knew using skills that are closely tied to an academic's work as an educator.

By listening as well as talking, I learned a great deal and then tried to share that information across divides. Because I am White and relatively privileged and had no background in criminal justice, I learned a great deal from Black people and criminal justice professionals and tried to share that knowledge with White people who were not part of the system.

I learned the most when I had the privilege of being part of Black-organized events dominated by Black people talking to each other. The people closest to the problem thought that the criminal justice system is unfair and racist, but they also thought crime was a problem in their communities. I was a co- 
panelist with a Black community member in Milwaukee who was organizing a "stop the murders" campaign and trying to get more police presence in her neighborhood. She thought I was right about the system being racially unfair but also thought you had to do something about the murders. I heard many Black people advocating teaching Black children how to avoid escalating encounters with police as a way of dealing with what they see as racist policing, similar to what Jones (2018) reports. In one debate among Black people (I was the only White present), a criminal justice professional who is outspoken about the problem of racism in the system said young people had to be taught not to argue or struggle with police because assaulting an officer is a felony. Someone else made the point that the kids struggle with police because they are being mistreated. She said, "Yes of course they are being mistreated." Then she recounted her first experience with the police as a young teen, when she and her brothers were doing nothing wrong, just walking down the street, and her brothers were thrown to the ground by police because a crime had been committed nearby. She said, "I know why they don't like the police. But it ruined their lives." She and other Black activist professionals also expressed concerns about Black children who seemed angry, out of control, and unreachable and about Black children organizing gang fights on social media. They absolutely believed that racism was the underlying problem, but they also thought they needed to find ways to reach the children and try to get them off self-destructive paths. This same combination of critique of racist policing and attention to ways of redeeming people's lives animates the work of scholars of color like Victor Rios (2011) and Nikki Jones (2018).

I learned from criminal justice professionals about the complexities of their jobs and the ways in which they can simultaneously perceive the racial consequences of the systems they are enacting and feel unable to change them. I talked with Black and Latino officers who thought crime in minority communities was a serious problem and that policing had to be concentrated where crime was a problem, but also thought that these policing patterns were producing unfair results. I talked with a White police officer who had discussed putting undercover officers in a White trailer park at the edge of town where they knew there were drug sales going on and said that other officers had been confused about why they would want to do that. I talked with White police who said it is impossible to discriminate in traffic stops because you cannot see a driver's race until after they are stopped and to Black police who thought others were profiling. I learned that routinely running license numbers in the patrol car computer was one way to choose whom to stop. At a large meeting of police officers, where the original agenda was for several White professors to talk about how to improve community relations, the discussion turned to include Black officers' perceptions of discrimination in how policing worked and how the structure of advancement as a police officer hindered Black officers who tried to form better connections with Black community members. I talked with prosecutors who thought some of their fellow prosecutors were racist and others who emphasized the stresses of the position. I learned from Deputy Sheriffs that officers may shoot unarmed people because they fear losing control of their own weapon and lack the physical conditioning to deal with someone who is struggling.

Even after a decade of participation, I found the complexities of the criminal justice system to be confusing and often contradictory. I learned that criminal justice professionals themselves also did not understand the whole system. They often disagreed about the facts about how the system worked or did not understand the extent of variation between places and actors. Although most people attribute prison sentences to judges, I learned indirectly from conversations at meetings that in my county the sentences in plea bargains were never contested before the judge, so that judges effectively had no role in most sentences, while this was not true in other counties. A judge on a task force insisted that it could not possibly be true that people were being held in jail on cash bail for minor offenses because he saw many people released on signature bond, even though other information contradicted his belief. Data on the prevalence of the problem were not available to definitively settle the debate. 
Many parolees, their families, and people who work in reentry told stories of capricious and arbitrary re-incarceration of people on parole. The local district attorney, corrections officials, and some judges insisted that this could not be true because all revocations required a court hearing. However, a court commissioner and multiple public defenders said that many parolees are persuaded by their parole officer to waive their hearings. The Department of Corrections kept no data on whether a hearing had been held before revocation. Additionally, incarceration from parole happened without formal revocation, both as a "hold," typically for a few days or weeks but sometimes for months or even years, while someone investigates whether a revocation is warranted, and as an "alternative to revocation," a short-term incarceration without a formal revocation. From some professionals' perspectives, these facts were simply invisible.

\section{Amplifying the voices of the marginalized}

Like any other advantaged ally, engaged academics should be especially attentive to listening to the people closest to the problem and trying to amplify the voices of the oppressed and marginalized. Exprisoners or low-income people often provided information that was shocking or even unbelievable for the more privileged group members. Much of this came in testimony in public hearings before commissions and task forces. A young White woman whose father was incarcerated for sexually abusing her talked about her family being thrown into poverty. Many people talked about ankle bracelets malfunctioning, and one malfunctioned in the middle of a hearing with DOC officials present. A young man testified that police had planted drugs on him during a traffic stop. Many people testified about rude and discriminatory behavior by criminal justice professionals. A Black professional spoke of being shocked and distressed to learn how bad things were for the families of the children his son encountered in a first year of teaching.

Ida Thomas, a Black community member on the county task force, whose son had been incarcerated and who said she was "uneducated" because she quit school after the $9^{\text {th }}$ grade but not "low income" because she had a disability pension, wrote a statement for the report and asked me to represent her at a meeting she could not attend and edit the statement so it would not sound uneducated. She also gave me permission to publish parts of it on a blog with her name on it. ${ }^{i}$ She wanted her voice heard and her name named even as she was concerned about how she would be perceived.

Many laws and regulations effectively incarcerated people for not having money. Incarceration was a penalty for non-payment of child support, even when it was known the person had lost their job. Fines for municipal tickets for things like noise ordinance violations or driving without a license led to bench warrants and incarceration if the fines could not be paid. Many people drove without a license because people under 18 could not get a license without paying $\$ 400$ for a driver education course, the written test requires a high literacy level, licenses could be suspended even before you had a license (the suspension would be waiting for you when you first applied for a license) for a wide variety of offenses that had nothing to do with driving, and the penalty for driving without a license was suspension of your license until you paid a large fine. With an inadequate public transportation system, people must drive to hold jobs. People really did end up incarcerated for driving without a license.

Amplifying marginalized voices often led to conflict. Both the governor's commission and the county task force were dominated by reformers but also included White professionals who overtly expressed concern that they or their institutions would be accused of racism and saw their role as generating a report that everybody could agree to. Both groups held hearings designed to solicit experiences and information from "the community." This testimony was compiled into an appendix of the governor's commission report with little controversy but also little impact on the main body of the report. Treatment of the testimony became a source of acrimony in the county task force, which had more non- 
professional members. Some [White] law enforcement and corrections officials argued that it was unfair to summarize citizen complaints because they were one-sided, unverified or a biased sample. The police representative objected to a Latino's story of being stopped a dozen times after the big immigration rally. "It makes us look bad," he said, even though newspapers had reported that a "renegade" officer had been disciplined for stopping Latinos at extraordinarily high rates. There were even objections to including the statement "there is widespread perception of bias" in the report because it wasn't based on a scientific sample of the community, even though this perception was the reason the task force existed! Supported by me and others on the committee, a Hispanic man successfully pled for the inclusion of people's voices in the report, although a few of the more inflammatory statements were excised and a statement about unrepresentativeness was added.

There were also conflicts that arose from racial-cultural differences in the rules for expressing disagreement and talking about race. Black people who expressed themselves in challenging ways were often not "heard" but instead were responded to with withdrawal or offense. One Black woman waited quietly for her turn, was interrupted when she began voicing her complaints about the group's process, and then received expressions of anger when she objected to being interrupted after waiting her turn. Nobody ever called any other person in the room racist at any meeting I attended, but even generic complaints about racism or discrimination or racial bias evoked negative reactions from some Whites, even though addressing racial bias was the stated purpose of the group. One White person said they could not stay at the table if people were going to be called racist when the Black man who ran a reentry project used the word "racist" to complain about the all-White construction crews in public works. The context was job opportunities for ex-felons, there had already been general discussion of the problem of employment discrimination, and the point was clearly that construction firms getting public money should hire Black people. But the r-word was still explosive for some Whites, even in context.

\section{Conclusions}

Like other activist professionals, sociologists can use their professional skills to support movements by and for oppressed and marginalized people. Like all activists, activist professionals have opinions about what causes to support and what actions to take that are grounded in their own experience and backgrounds. I became engaged as a volunteer, not as a professional, but I could not help but bring my sociological self into my work. My own agenda came to be using quantitative data to hold powerful people and systems accountable, a different agenda from a common sociological approach that asks whether racial differences can be explained away with control variables. But I did not naively assume that all statistical disparities were due to simple discrimination. I understood that oppressive systems could also contribute to people being violent or committing economic crimes. As I participated, I listened to and came to have great respect for the other people who were part of the system, both the professionals working in it and the community people impacted by it. I came to see my role as both distinctive and as like that of other activist professionals. I brought something to the table, but it was only useful when combined with what other people brought.

Like other activist professionals, sociologists can be ignorant of things outside their own professional sphere. My research skills and my broad sociological view contributed to the movement, but I came to recognize that the broad academic view could be oblivious to what was happening on the ground and that sociologists can form wrong ideas about causal processes if they are too far removed from the problem or looking at data from only one part of the system. Further, drawing policy implications from data is not straightforward. It is easier to provide a social critique and evidence of a problem than it is find effective ways to pursue justice and undo the damage of past policies in the face of adverse political 
and economic constraints. It is easier just to give your own perspective and go home than it is to sit through meetings and try to reach some sort of accord with people who don't all agree.

Like other advantaged allies, I sometimes had undue influence because of my resources and privilege and sometimes alienated others with my personal or cultural style. I often observed conflicts in groups arising from differences in customary practices, access to resources, differences of interest, and differences in the culture of how disagreements are expressed. Like many other professional activists, I sought to do what I could to bridge these differences when I recognized them and to acknowledge and amplify the voices of less privileged or more marginalized people.

Just as the Task Force danced around the question of whether "culturally appropriate" services required people who themselves were members of the cultural groups in question, White middle-class academics dance around the question of whether we can adequately represent the voices and interests of marginalized communities. An implication is that people from majority or advantaged backgrounds should be trying to welcome people from marginalized communities into the academy, so they can provide culturally appropriate research services.

Academic sociologists can and should recognize our own interests and our desire for secure jobs, to feel important and respected, and to advance in our careers. Building relations and becoming embedded in groups trying to find solutions broadens understanding but it takes a lot of time, time that is not spent writing, publishing and advancing a career. This is not a complaint. Academics and other professionals with dependable jobs and good salaries are privileged and part of our privilege is that we are not living at the margins, we do have choices. Complaining about having to make choices is absurd. Instead we can make those choices consciously and seek to persuade others to make them consciously. We can choose how much of our time to spend working for social change, advancing our individual careers, challenging the structures of the academy, or spending time with our families and in leisure activities. Even as we are aware of the professional risks of speaking out too noisily or failing to meet the performance metrics of the corporatized university, we can remember that oppressed activists have often suffered stress-related illnesses and unemployment. We can remember that other people are also making choices and sacrifices, often under more severe constraints than our own. 


\section{References}

Abraham, Margaret, and Gregory M. Maney. 2012. "Transforming place and belonging through action research, community practice, and public policy: Comparing responses to NIMBYism." Current Sociology 60(2):178-201.

Appel, Liz. 2003. "White Supremacy in the Movement against the Prison-Industrial Complex." Social Justice 30(2):81-88.

Azab, Marian, and Wayne A. Santoro. 2017. "RETHINKING FEAR AND PROTEST: RACIALIZED REPRESSION OF ARAB AMERICANS AND THE MOBILIZATION BENEFITS OF BEING AFRAID." Mobilization 22(4):473-91.

Bell, Joyce Marie. 2014. "The Black power movement and American social work." Pp. 1 online resource (xvii, 235 pages). New York: Columbia University Press,.

Berkhalter, Denise L. 2006. "Behind the Boycott." The Crisis 113(2):22-23.

Bradbury-Huang, Hilary. 2010. "What is good action research? Why the resurgent interest?" Action Research 8(1):93-109.

Brady, Shane R., and Jacob Lesniewski. 2018. "Rabble Rousing in a Red State: Lessons Learned From Organizing for Worker Rights in a Highly Conservative State." Journal of Community Practice 26(2):236-51.

Brewer, Rose M. 2005. "Response to Michael Buroway's Commentary: "The Critical Turn to Public Sociology"." Critical Sociology (Brill Academic Publishers) 31(3):353-59.

Brook, Paul, and Ralph Darlington. 2013. "Partisan, scholarly and active: arguments for an organic public sociology of work." Work, Employment \& Society 27(2):232-43.

Brown, Melissa. 2017. "The sociology of antiracism in Black and White." Sociology Compass 11(2):e12451.

Brydon-Miller, Mary, Davydd Greenwood, and Patricia Maguire. 2003. "Why action research?": Sage Publications.

Burawoy, Michael. 2005. "2004 PRESIDENTIAL ADDRESS: For Public Sociology." American Sociological Review 70(1):4-28.

Burawoy, Michael, William Gamson, Charlotte Ryan, Stephen Pfohl, Diane Vaughan, Charles Derber, and Juliet Schor. 2004. "Public Sociologies: A Symposium from Boston College." Social Problems 51(1):103-30.

Burciaga, Edelina M. 2016. "'With or Without DACA, I'm still undocumented:" The educational experiences of undocumented young adults in California and Georgia." Conference Papers -American Sociological Association:1-24.

Burciaga, Edelina M., and Lisa M. Martinez. 2017. "HOW DO POLITICAL CONTEXTS SHAPE UNDOCUMENTED YOUTH MOVEMENTS? EVIDENCE FROM THREE IMMIGRANT DESTINATIONS." Mobilization 22(4):451-71.

Cancian, Francesca M. 1993. "Conflicts Between Activist Research and Academic Success: Participatory Research and Alternative Strategies." American Sociologist 24(1):92-106.

Carragee, Kevin M. 2005. "5. Housing crisis : gaining standing in a community coalition." Pp. 79-96 in Rhyming hope and history : activists, academics, and social movement scholarship, edited by David Croteau, William Hoynes, and Charlotte Ryan. Minneapolis: University of Minnesota Press.

Chappell, L. 2002. "The 'femocrat' strategy: Expanding the repertoire of feminist activists." Parliamentary Affairs 55(1):85-+.

Croteau, David. 2005. "2. Which side are you on? : the tension between movement scholarship and activism." Pp. 20-40 in Rhyming hope and history : activists, academics, and social movement 
scholarship, edited by David Croteau, William Hoynes, and Charlotte Ryan. Minneapolis: University of Minnesota Press.

David, Matthew. 2002. "Problems of participation: the limits of action research." International Journal of Social Research Methodology 5(1):11-17.

Dawson, Marcelle C., and Luke Sinwell. 2012. "Ethical and Political Challenges of Participatory Action Research in the Academy: Reflections on Social Movements and Knowledge Production in South Africa." Social Movement Studies 11(2):177-91.

Droogendyk, Lisa, Stephen C. Wright, Micah Lubensky, and Winnifred R. Louis. 2016. "Acting in Solidarity: Cross-Group Contact between Disadvantaged Group Members and Advantaged Group Allies." Journal of social issues 72(2):315-34.

Emejulu, Akwugo. 2015. "Minority women, austerity and activism." Race \& Class 57(2):86-95. Feagin, Joe R., and Hernán Vera. 2001. Liberation sociology. Boulder, Colo.: Westview Press.

Feagin, Joe R., Hernán Vera, and Kimberley Ducey. 2015. Liberation Sociology. 3rd Edition.: Paradigm. Gamson, William A. . 2005. "Afterword." Pp. 265-79 in Rhyming hope and history : activists, academics, and social movement scholarship, edited by David Croteau, William Hoynes, and Charlotte Ryan. Minneapolis: University of Minnesota Press.

Gedicks, Al. 2004. "LIBERATION SOCIOLOGY AND ADVOCACY FOR THE SOKAOGON OJIBWE." Organization \& Environment 17(4):449-70.

Goodson, Adria D. 2005. "12. Building bridges, building leaders : theory, action, and lived experience." Pp. 206-21 in Rhyming hope and history : activists, academics, and social movement scholarship, edited by David Croteau, William Hoynes, and Charlotte Ryan. Minneapolis: University of Minnesota Press.

Greenwood, Davydd J, and Morten Levin. 2006. Introduction to action research: Social research for social change: SAGE publications.

Healey, Richard, and Sandra Hinson. 2005. "4. Movement strategy for organizers." Pp. 57-75 in Rhyming hope and history : activists, academics, and social movement scholarship, edited by David Croteau, William Hoynes, and Charlotte Ryan. Minneapolis: University of Minnesota Press.

Hill Collins, Patricia. 1986. "Learning from the Outsider Within: The Sociological Significance of Black Feminist Thought." Social Problems 33(6):14.

-. 2009. Black feminist thought: knowledge, consciousness, and the politics of empowerment. New York: Routledge.

—. 2016. "Du Bois's contested legacy." Ethnic \& Racial Studies 39(8):1398-406.

Hoynes, William. 2005. "6. Media research and media activism." Pp. 97-114 in Rhyming hope and history : activists, academics, and social movement scholarship, edited by David Croteau, William Hoynes, and Charlotte Ryan. Minneapolis: University of Minnesota Press.

Hughey, Matthew W. 2007. "Racism With Antiracists: Color-Conscious Racism And The Unintentional Persistence Of Inequality." Social Thought \& Research 28(1/2):67-108.

Johnston, Paul. 2007. "Constituting a Practical Public Sociology: Reflections on Participatory Research at the Citizenship Project." Conference Papers -- American Sociological Association:1.

Jones, Nikki. 2018. The Chosen Ones: Black Men and the Politics of Redemption. Berkeley, CA: University of California Press.

Khadse, Ashlesha, Peter Michael Rosset, Helda Morales, and Bruce G. Ferguson. 2018. "Taking agroecology to scale: the Zero Budget Natural Farming peasant movement in Karnataka, India." Journal of Peasant Studies 45(1):192-219.

Luna, Zakiya. 2016. "“Truly a Women of Color Organization”." Gender \& Society 30(5):769-90.

—. 2017. "WHO SPEAKS FOR WHOM? (MIS) REPRESENTATION AND AUTHENTICITY IN SOCIAL MOVEMENTS." Mobilization 22(4):435-50. 
-. 2018. "“Black Children Are an Endangered Species": Examining Racial Framing in Social Movements." Sociological Focus 51(3):238-51.

Luna, Zakiya T. 2010. "Marching Toward Reproductive Justice: Coalitional (Re) Framing of the March for Women's Lives." Sociological Inquiry 80(4):554-78.

-. 2011. "The Phrase of the Day': Examining Contexts and Co-optation of Reproductive Justice Activism in the Women's Movement." Research in Social Movements, Conflict and Change 32:219-46.

Maney, Gregory M., and Margaret Abraham. 2008. "Whose Backyard? Boundary Making in NIMBY Opposition to Immigrant Services." Social Justice 35(4):66-82.

Martinez, Lisa M. 2005. "Yes We Can: Latino Participation in Unconventional Politics." Social Forces 84(1):135-55.

-. 2008. "'Flowers From the Same Soil": Latino Solidarity in the Wake of the 2006 Immigrant Mobilizations." American Behavioral Scientist 52(4):557-79.

-. 2014. "Dreams Deferred: The Impact of Legal Reforms on Undocumented Latino Youth." American Behavioral Scientist 58(14):1873-90.

Marx, Gary T., and Michael Useem. 1971. "Majority Involvement in Minority Movements: Civil Rights, Abolition, Untouchability." The Journal of Social Issues 27(1):81-104.

McCarthy, John D., and Mayer N. Zald. 1977. "Resource Mobilization and Social Movements: A Partial Theory." American Journal of Sociology 82(6):1212-41.

Morris, Aldon, and Amin Ghaziani. 2005. "DuBoisian Sociology." Souls: A Critical Journal of Black Politics, Culture \& Society 7(3/4):47-54.

Morton, Mavis, Corey Dolgon, Timothy Maher, and James Pennell. 2012. "Civic Engagement and Public Sociology: Two "Movements"in Search of a Mission." Journal of Applied Social Sciences (19367244) 6(1):5-30.

Oliver, Pamela. 1983. "THE MOBILIZATION OF PAID AND VOLUNTEER ACTIVISTS IN THE NEIGHBORHOOD MOVEMENT." Research in Social Movements, Conflicts \& Change 5:133-70.

-. 2008. "Repression and Crime Control: Why Social Movement Scholars Should Pay Attention to Mass Incarceration as a Form of Repression." Mobilization: An International Quarterly 13(1):1-24.

—. 2009. "Talking About Racial Disparities in Imprisonment: A Reflection on Experiences in Wisconsin." in Handbook of public sociology, edited by Vincent Jeffries: Rowman and Littlefield.

-. 2011. " Providing Useful Knowledge, Becoming Embedded: Issues and Tensions as a Racial Justice Ally." in Plenary presentation at the 2011 Conference of the Collective Behavior and Social Movements Section of the American Sociological Association. Las Vega, Nevada: Available at https://osf.io/preprints/socarxiv/km72c/.

Oslender, Ulrich 2015. "Leaving the Field: How to Write about Disappointment and Frustration in Collaborative Research." Pp. 63-74 in Bridging scholarship and activism : reflections from the frontlines of collaborative research, edited by Bernd Reiter and Ulrich Oslender. East Lansing, Michigan: Michigan State University Press,.

Peters, Cynthia. 2005. "3. Knowing what's wrong is not enough : creating strategy and vision." Pp. 41-56 in Rhyming hope and history : activists, academics, and social movement scholarship, edited by David Croteau, William Hoynes, and Charlotte Ryan. Minneapolis: University of Minnesota Press.

Reiter, Bernd 2015. "Of Academic Embeddedness: Communities of Choice and How to Make Sense of Activism and Research Abroad." Pp. 3-14 in Bridging scholarship and activism : reflections from the frontlines of collaborative research, edited by Bernd Reiter and Ulrich Oslender. East Lansing, Michigan: Michigan State University Press,.

Reiter, Bernd, and Ulrich Oslender. 2015. "Bridging scholarship and activism : reflections from the frontlines of collaborative research." Pp. 1 online resource (229 p in Transformations in Higher Education: the Scholarship of Engagement. East Lansing, Michigan: Michigan State University Press,. 
Rios, Victor M. 2011. Punished: Policing the lives of Black and Latino boys: NYU Press.

Ross, Robert J. S. . 2005. "10. Sweatshop labor : (re)framing immigration." Pp. 176-88 in Rhyming hope and history : activists, academics, and social movement scholarship, edited by David Croteau, William Hoynes, and Charlotte Ryan. Minneapolis: University of Minnesota Press.

Ryan, Charlotte. 2005. "7. Successful collaboration : movement building in the media arena." Pp. 115-36 in Rhyming hope and history : activists, academics, and social movement scholarship, edited by David Croteau, William Hoynes, and Charlotte Ryan. Minneapolis: University of Minnesota Press.

Ryan, Charlotte , Karen Jeffreys, and Linda Blozie. 2012. "4. Raising Public Awareness of Domestic Violence: Strategic Communication and Movement Building." Pp. 61-92 in Strategies for social change, edited by Gregory M. Maney. Minneapolis, MN: University of Minnesota Press,.

Sawer, M. 2007. Australia: the Fall of the Femocrat.

Schiller, Nina Glick. 2011. "Scholar/Activists and Regimes of Truth: Rethinking the Divide between Universities and the Streets." Transforming Anthropology 19(2):162-64.

Sekhon, Joti. 2006. "Engendering Grassroots Democracy: Research, Training, and Networking for Women in Local Self-Governance in India." NWSA Journal 18(2):101-22.

Stoecker, Randy. 1999. "Are academics irrelevant?" American Behavioral Scientist 42(5):840.

Stoecker, Randy, and Edna Bonacich. 1992. "Why Participatory Research? Guest Editors' Introduction." Pp. 5 in American Sociologist: Springer Science \& Business Media B.V.

\footnotetext{
i https://scatter.wordpress.com/2009/06/30/turf/
} 